Check for updates

Cite this: RSC Adv., 2019, 9, 8638

\title{
Fully automated peptide radiolabeling from $\left[{ }^{18} \mathrm{~F}\right]$ fluoride $\uparrow$
}

\author{
Ryan A. Davis, (D) ${ }^{\text {ac }}$ Chris Drake, ${ }^{\text {b }}$ Robin C. Ippisch, ${ }^{\mathrm{c}}$ Melissa Moore ${ }^{\mathrm{b}}$ \\ and Julie L. Sutcliffe (D) *acd
}

The biological properties of receptor-targeted peptides have made them popular diagnostic imaging and therapeutic agents. Typically, the synthesis of fluorine-18 radiolabeled receptor-targeted peptides for positron emission tomography (PET) imaging is a time consuming, complex, multi-step synthetic process that is highly variable based on the peptide. The complexity associated with the radiolabeling route and lack of robust automated protocols can hinder translation into the clinic. A fully automated batch production to radiolabel three peptides (YGGFL, CRGDyK, and Pyr-QKLGNQWAVGHLM) from fluorine-18 using the ELIXYS FLEX/CHEM® radiosynthesizer in a two-step process is described. First, the prosthetic group, 6- $\left[{ }^{18} \mathrm{~F}\right]$ fluoronicotinyl-2,3,5,6-tetrafluorophenyl ester $\left(\left[{ }^{18} \mathrm{~F}\right] \mathrm{FPy}\right.$-TFP) was synthesized and subsequently attached to the peptide. The $\left[{ }^{18} \mathrm{~F}\right] \mathrm{FPy}$-peptides were synthesized in $13-26 \%$ decay corrected yields from fluorine-18 with high molar activity $1-5 \mathrm{Ci}_{\mu} \mathrm{mol}^{-1}$ and radiochemical purity of $>99 \%$ in an overall synthesis time of $97 \pm 3$ minutes.

Received 24th December 2018 Accepted 26th February 2019

DOI: 10.1039/c8ra10541c

rsc.li/rsc-advances

against a target epitope, facilitating identification and optimi-

\section{Introduction}

Peptide-based pharmaceuticals have applications in both diagnostic imaging and targeted therapy with more than 60 approved by the US Food and Drug Administration (FDA), 140 in clinical trials (half of which are diagnostic imaging agents), and approximately another 500 in pre-clinical development., Peptides have numerous characteristics that make them ideal as radiotracers; in particular, their biological half-life ideally matches the radioactive half-life of many radionuclides currently being used for positron emission tomography (PET), such as gallium-68, fluorine-18, and copper- $64 .{ }^{3}$ They are relatively small in size $(\sim 0.5$ to $10 \mathrm{kDa})$ and exhibit short in vivo circulation times ( $\mathrm{min}$ to $\mathrm{h}$ ) that result in rapid clearance from the blood pool and non-targeted tissues. ${ }^{4}$ Peptides have demonstrated similar binding affinities as antibodies for their respective targets but are simpler to prepare, typically nonimmunogenic, and can be easily chemically modified to further improve affinity, selectivity, stability, and their pharmacokinetic profile. ${ }^{3}$ Moreover, contemporary molecular biology and peptide combinatorial library techniques allow large peptide libraries to be generated and rapidly screened

\footnotetext{
${ }^{a}$ Department of Internal Medicine, Division of Hematology and Oncology, University of California, Davis, CA, USA. E-mail: jlsutcliffe@ucdavis.edu; Fax: +1-916-734-7572; Tel: $+1-916-734-5536$

${ }^{b}$ Sofie Co., Culver City, CA, USA

'Department of Biomedical Engineering, University of California, Davis, CA, USA

${ }^{d}$ Center for Molecular and Genomic Imaging, University of California, Davis, CA, USA

$\dagger$ Electronic supplementary information (ESI) available: HPLC-chromatograms and mass spectra. See DOI: 10.1039/c8ra10541c
}

zation of high affinity peptide ligands. ${ }^{5}$

One of the first examples of a peptide radiotracer translated to the clinic was $\left[{ }^{123} \mathrm{I}\right]-\mathrm{Tyr}^{3}$-octreotide, used to image somatostatin receptor density in patients with neuroendocrine tumors (NETs). ${ }^{6}$ Octreotide was later optimized and radiolabeled with indium-111 for single photon computed tomography (SPECT), and since then octreotide has been radiolabeled with PETradionuclides including gallium-68 and fluorine-18, offering greater sensitivity and higher resolution images that provide for a more accurate diagnosis. ${ }^{6-11}$ Somatostatin imaging has become the standard-of-care for patients with NETs, with sensitivities and specificities of $>90 \%$, and the combination of somatostatin imaging with computed tomography (CT) or magnetic resonance imaging (MRI) has been reported to change clinical treatment for $20-60 \%$ of patients. ${ }^{11}$ The FDA approval of NETSPOT ( ${ }^{68} \mathrm{Ga}$-DOTATATE) in 2016 underscores the success of peptide radiotracers currently used in the clinic. ${ }^{12}$

Several other disease associated cellular-receptors have been targeted with peptide radiotracers for both imaging and radiotherapy. For example the integrin- $\alpha_{v} \beta_{3}$, which is overexpressed in a number of cancers, including melanoma, breast, and head and neck as well as neo-angiogenic blood vessels. ${ }^{13-16}$ The integrin- $\alpha_{v} \beta_{3}$ is involved in a number of cellular processes, including cell proliferation, migration, and tumor metastasis, and has been widely studied as a target for both imaging and therapy using small peptides containing an arginine-glycineaspartic acid (RGD)-motif. ${ }^{\mathbf{1 3 - 1 9}}$ Another member of the integrin family of receptors that is currently being investigated is the integrin- $\alpha_{v} \beta_{6}$, an epithelial-specific cell surface receptor that is 
undetectable in healthy adults, but is significantly up-regulated in a wide range of epithelial derived cancers including, pancreas, colon, non-small cell lung cancer, ovarian, breast, prostate, and oral squamous cell carcinoma. ${ }^{20-26}$ Sutcliffe et al., have focused significant effort on the development of $\alpha_{v} \beta_{6}$-targeting peptides based on the 20 amino acid sequence derived from an envelope protein of the foot-and-mouth disease virus. ${ }^{23-26}$ Another example are the gastrin releasing peptide receptors (GRPRs) that are overexpressed in many cancers, including breast, pancreatic, and prostate, with GRPR-mediated signalling being linked to several oncogenic processes such as invasiveness and proliferation..$^{27,28}$ These receptors have been targeted by a series of bombesin peptides for both imaging and therapeutic purposes with their efficacy being examined in several clinical studies. ${ }^{27,28}$

Fluorine-18 is a favored radioisotope for radiolabeling peptides due to its nuclear and physiochemical characteristics for in vivo imaging, including a half-life (109.77 $\mathrm{min})$ that closely matches the pharmacokinetics of peptides, low $\beta^{+}$ energy $(0.64 \mathrm{MeV})$, high $97 \% \beta^{+}$emission, and is readily available in sufficient quantities (10-20 Ci) and high molar activity (1-10 Ci $\mu \mathrm{mol}^{-1}$, required for receptor-targeting imaging). ${ }^{29,30}$ Radiolabeling of peptides with fluorine-18 is mainly carried out using a prosthetic group, a small, bifunctional molecule that is first reacted with the radioisotope with subsequent attachment to the peptide at the $N$-terminal amine, the $N \varepsilon$-amine of a lysine residue, or a thiol of a cysteine residue. ${ }^{4}$ Examples of aminereactive prosthetic groups include $N$-succinimidyl $4-\left[{ }^{18} \mathrm{~F}\right]$ fluorobenzoate ([ $\left.\left.{ }^{18} \mathrm{~F}\right] \mathrm{SFB}\right), 4-\left[{ }^{18} \mathrm{~F}\right]$ fluorobenzoic acid $\left(\left[{ }^{18} \mathrm{~F}\right] \mathrm{FBA}\right)$, and 6- $\left[{ }^{18} \mathrm{~F}\right]$ fluoronicotinic acid 2,3,5,6-tetrafluorophenyl ester $\left(\left[{ }^{18} \mathrm{~F}\right]\right.$ FPy-TFP). ${ }^{4}$ Thiol-reactive prosthetic groups include maleimide-

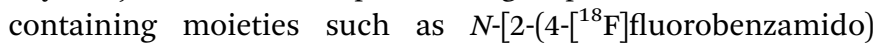
ethyl $]$ maleimide $\quad\left(\left[{ }^{18} \mathrm{~F}\right] \mathrm{FBEM}\right) \quad$ and $\quad N$-[6- $\left(4-\left[{ }^{18} \mathrm{~F}\right]\right.$ fluorobenzylidene)aminooxyhexyl $]$ maleimide $\quad\left(\left[{ }^{18} \mathrm{~F}\right] \mathrm{FBAM}\right) .{ }^{4} \quad$ Noncanonical functional groups can also be incorporated into peptides to facilitate radiolabeling using ${ }^{18} \mathrm{~F}$-prosthetics such as 4- $\left[{ }^{18} \mathrm{~F}\right]$ fluorobenzaldehyde, $\quad 2-\left[{ }^{18} \mathrm{~F}\right]$ fluorodeoxyglucose $\quad\left(\left[{ }^{18} \mathrm{~F}\right]\right.$ FDG), and click-moieties such as $\left[{ }^{18} \mathrm{~F}\right]$ fluoro-trans-cyclooctene. ${ }^{29,30}$ The use of a prosthetic group to radiolabel peptides from fluorine-18 is generally required as direct incorporation into the peptide is not feasible due to the harsh reaction conditions required for $\mathrm{C}-\mathrm{F}$ bond formation (e.g. high temperatures or strongly basic conditions). ${ }^{4}$ Traditionally, synthesis of the prosthetic group is performed manually. ${ }^{31}$

Automation of the radiosynthesis can provide a safe, reproducible, straight-forward route to radiolabel any peptide from fluorine-18. Unfortunately to date automated procedures have primarily focused on small molecules or the production of prosthetic groups. ${ }^{4}$ Several automated syntheses of ${ }^{18} \mathrm{~F}$ prosthetics used for peptide radiolabeling have been reported, including $\left[{ }^{18} \mathrm{~F}\right] \mathrm{SFB},{ }^{32}\left[{ }^{18} \mathrm{~F}\right] \mathrm{FBEM},{ }^{32}\left[{ }^{18} \mathrm{~F}\right] \mathrm{FBA},{ }^{32}$ azido- $\left[{ }^{18} \mathrm{~F}\right]$ fluorosugars, ${ }^{33}\left[{ }^{18} \mathrm{~F}\right]$ hexafluorobenzene, ${ }^{34}$ and $\left[{ }^{18} \mathrm{~F}\right]$ fluoroethylazide. ${ }^{35}$ The radiochemical yields for these automated productions are comparable, if not better than the analogous manual protocols. ${ }^{32-35}$ Automated protocols capable of generating ${ }^{18} \mathrm{~F}$ peptides from fluorine-18 without manual interventions are less prevalent, as multiple purifications are typically needed for both the intermediate ${ }^{18} \mathrm{~F}$-prosthetic and the final ${ }^{18} \mathrm{~F}$-peptide radiotracer. $^{4,31}$ For example, Thonon et al., used the FASTLab $^{\text {TM }}$ GE synthesis module for the production of $\left[{ }^{18} \mathrm{~F}\right] \mathrm{SFB}$ via both a one- and two-pot method, followed by coupling to an RGD peptide (PRGD2). ${ }^{36}$ Ackermann et al. also reported the fully automated radiolabeling of the protein glutathione with $\left[{ }^{18} \mathrm{~F}\right]$ FBEM the thiol reactive prosthetic group on an iPHASE FLEXLab module, however no extension of this methodology to radiolabeling a clinically-relevant peptide was included in this paper. ${ }^{37}$ Both methods required some form of manual intervention, and to our knowledge a fully automated procedure for the radiosynthesis of a clinically relevant fluorine-18 radiolabeled peptide has yet to be reported. ${ }^{4}$ Therefore, the goal of this work was to develop a fully automated ${ }^{18} \mathrm{~F}$-peptide radiolabeling synthesis and apply it to three clinically relevant peptides (YGGFL (1), cRGDyK (2), and Pyr-QKLGNQWAVGHLM (3)) (Fig. 1) with no user intervention. To achieve this, the $\left[{ }^{18} \mathrm{~F}\right]$ FPy-TFP prosthetic group was synthesized on an ELIXYS FLEX/ CHEM ${ }^{\circledR}$ radiosynthesizer automated module and subsequently conjugated to each of the target peptides.

\section{Experimental}

\section{General}

Solvents and reagents were purchased from Acros Organics (Pittsburg, PA), Sigma Aldrich (St Louis, MO), and NovaBiochem (Darmstadt, Germany) unless otherwise stated, and used without further purification. All solvents used for automated synthesis were anhydrous extra dry over molecular sieves. Chromatography solvents were purchased from EMD Millipore (Chicago, IL) as HPLC-grade and used directly. All automated syntheses were performed on an ELIXYS FLEX/CHEM ${ }^{\circledR}$ radiosynthesizer (Sofie Co., Culver City, CA) using the exact same command sequence (S1). The ${ }^{19}$ F-reference standards were synthesized using commercially available 6-fluoronicotinic acid (TCI America, Portland, OR) and/or 2,3,5,6-tetrafluorophenol (Sigma-Aldrich, St. Louis, MO). These synthon's C12-RP-HPLC is provided for reference (S2 and S3) as they are the major byproducts observed during hydrolysis of the $\left[{ }^{18} \mathrm{~F}\right] \mathrm{FPy}-\mathrm{TFP}$ prosthetic group. Rink-amide resin, $N$-terminal fluorenylmethoxycarbonyl (Fmoc) protected amino acids and 1[bis(dimethylamino)methylene]-1H-1,2,3-triazolo[4,5-b]pyr-

idinium 3-oxid hexafluoro-phosphate (HATU) were purchased from GL Biochem (Shanghai, China) or NovaBiochem (Darmstadt, Germany). The peptides used for radiolabeling, cRGDyK (2) and Pyr-QKLGNQWAVGHLM (3) (Fig. 1) were purchased from AnaSpec (Fremont, California) and used without further purification. The fluorine-18 was produced by PETNET Solutions (Sacramento, California). The aqueous fluoride-18 (6-10 $\mathrm{mCi}$ per synthesis) was trapped onto a chromafix-PS- $\mathrm{HCO}_{3}$ anion exchange cartridge (Macherey-Nagel, Düren, Germany) (conditioned with $2 \mathrm{~mL}$ water). Purification cartridges C18SepPak-Plus and Oasis MCX-Plus-mixed cation exchange cartridge were purchased from Waters (Milford, MA, USA) (conditioned with $10 \mathrm{~mL}$ ethanol followed by $10 \mathrm{~mL}$ water). 

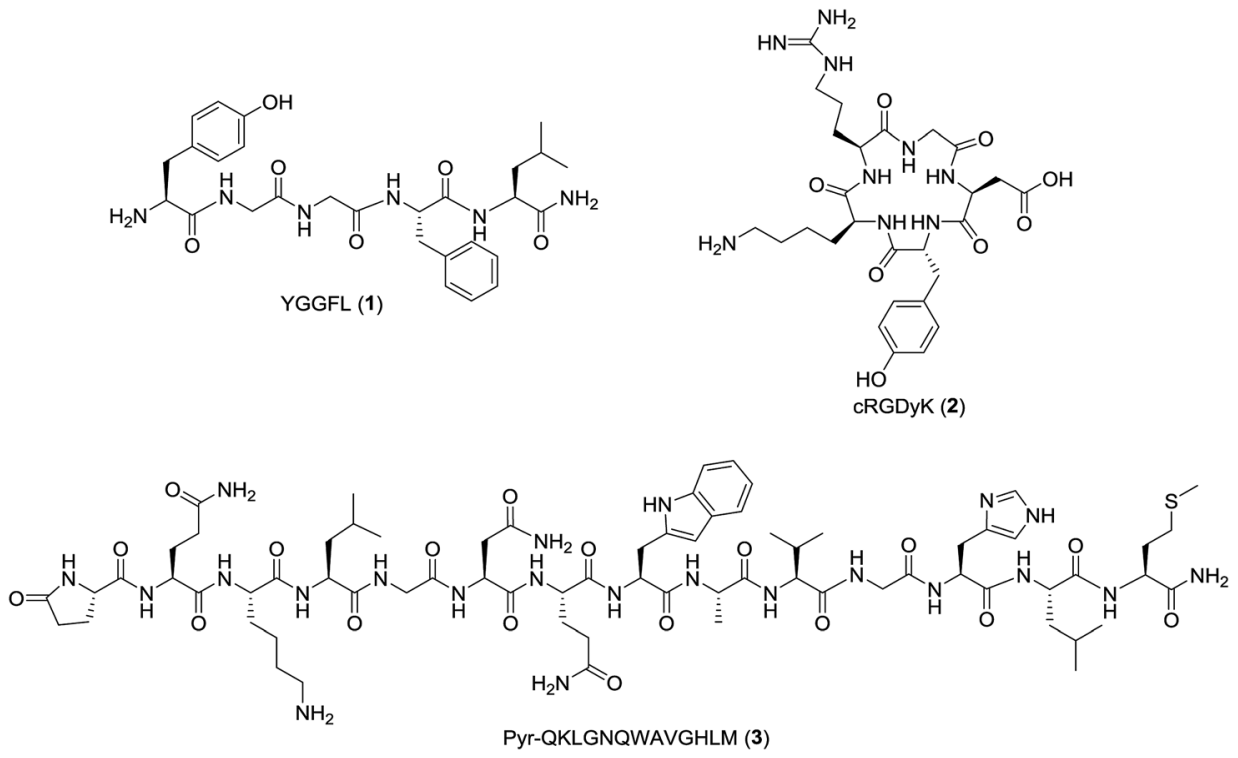

Fig. 1 Structures of the target peptides.

\section{HPLC conditions}

All peptides were purified and characterized using C12-RPHPLC using a Beckmann Coulter Gold HPLC system equipped with a $2 \mathrm{~mL}$ loop and a C12-Phenomenex-Jupiter $5 \mu \mathrm{m}$ Proteo 90 $\AA$ column $(250 \times 4.6 \mathrm{~mm}, 4 \mu \mathrm{m})$ with an ultraviolet (UV) absorbance detector $(220 \mathrm{~nm})$ and radioactivity detector (photomultiplier tube; Bioscan) connected in series. Mobile phase solvents were $0.05 \%$ trifluoroacetic acid in water (solvent $\mathrm{A}$ ) and $100 \%$ acetonitrile (solvent $\mathrm{B}$ ) with a gradient starting from $100 \%$ solvent A to $10 \%$ solvent B over $2 \mathrm{~min}$, then to $90 \%$ solvent B over $10 \mathrm{~min}$, held at $90 \% \mathrm{~B}$ for $5 \mathrm{~min}$, then returned to $100 \%$ solvent A over $5 \mathrm{~min}$, held at $100 \%$ solvent A for $3 \mathrm{~min}$ with a flow rate of $1.5 \mathrm{~mL} \mathrm{~min}^{-1}$.

\section{PyTFP-precursor (4) and ${ }^{19}$ FPy-TFP reference standard synthesis}

The precursor $N, N, N$-trimethyl-5-((2,3,5,6-tetrafluorophenoxy) carbonyl)pyridine-2-amminiumfluoro-methanesulfonate

Scheme 1) was synthesized using the slightly modified procedure as described by Olberg $e t$ al. ${ }^{38}$ 6-Chloronicotinic acid $(5.2 \mathrm{~g}$, $33.0 \mathrm{mmol}$ ) was activated with $N, N$-dicyclohexylcarbodiimide (DCC, $10.22 \mathrm{~g}, 49.51 \mathrm{mmol})$ in THF $(100 \mathrm{~mL})$ for 5 minutes followed by dropwise addition of 2,3,5,6-tetrafluorophenol $(6.58 \mathrm{~g}, 39.61 \mathrm{mmol})$ in THF (35 mL) and reacted overnight. The precipitate of $N, N$-dicyclohexylurea was removed by filtration and the reaction contents concentrated, washed with a saturated solution of sodium bicarbonate in dichloromethane, concentrated under reduced pressure and purified by silica-gel chromatography with a gradient solvent system starting from $10 \%$-ethyl acetate in $n$-hexanes increasing to $50 \%$-ethyl acetate in $n$-hexanes. The resulting ester $(7.8 \mathrm{~g}, 25.57 \mathrm{mmol})$ was dissolved in THF $(100 \mathrm{~mL})$, stirred vigorously while trimethylamine gas was bubbled through the reaction for 3 hours and stirred overnight. The reaction contents were then concentrated and the solid washed with diethyl ether. The resulting solid was suspended in dichloromethane $(200 \mathrm{~mL})$ and stirred vigorously while trimethylsilyl trifluoromethanesulfonate (TMSOTf, $10 \mathrm{~g}$, $44.99 \mathrm{mmol}$ ) was added dropwise via a syringe. The suspension was stirred for $15 \mathrm{~min}$ and the unreacted material filtered off with the reaction contents concentrated under reduced pressure and the resulting precipitate triturated with diethyl ether $(50 \mathrm{~mL})$. The product was collected by suction filtration and rinsed with diethyl ether $(50 \mathrm{~mL} \times 3)$. An X-ray crystal structure was obtained to confirm counter anion exchange ${ }^{39}$ and the HPLC retention time of the precursor (4) was $8.93 \mathrm{~min}$ (S4).

The ${ }^{19}$ FPy-TFP reference standard was prepared as previously described by Olberg et al. ${ }^{38}$ 6-fluoronicotinic acid (200 mg, 1.4 $\mathrm{mmol}$ ) was reacted with DCC (439 mg, $2.1 \mathrm{mmol})$ in THF (4 mL) for 5 minutes followed by dropwise-addition of 2,3,5,6-tetrafluorophenol (285 mg, $1.7 \mathrm{mmol}$ ) dissolved in THF (2 mL). After stirring overnight, the dicyclohexylurea was filtered off, the solvent concentrated, and the resulting ${ }^{19}$ FPy-TFP ester purified by silica-gel column chromatography in $90 \%-n$-hexanes and 10\%-ethyl acetate. The ${ }^{19}$ FPy-TFP ester reference standard was characterized per previous literature ${ }^{38}$ and had an HPLCretention time of $13.73 \mathrm{~min}$ (S5).

\section{Peptide synthesis of YGGFL (1)}

The $\mathrm{NH}_{2}$-YGGFL peptide (1, Fig. 1) was assembled on rink amide resin using traditional solid-phase fluorenylmethyloxycarbonyl (Fmoc)-chemistry with reiterative couplings (1.5 h) with Fmoc-amino acids (3 equiv.), HATU (2.8 equiv.) and DIPEA ( 6 equiv.) and Fmoc removal $(2 \times 15 \mathrm{~min})$ with 20\%-piperidine in $\mathrm{N}, \mathrm{N}$-dimethylformamide (DMF, 1 $\mathrm{mL}) .^{\mathbf{4 0 , 4 1}}$ Coupling and deprotection was monitored with a picryl sulfonic acid colorimetric test. ${ }^{41}$ After assembly, the peptide was globally deprotected and cleaved from the resin using trifluoroacetic acid/triisopropylsilane/water (TFA/TIPS/ $\mathrm{H}_{2} \mathrm{O}, 95 /$ 
A.

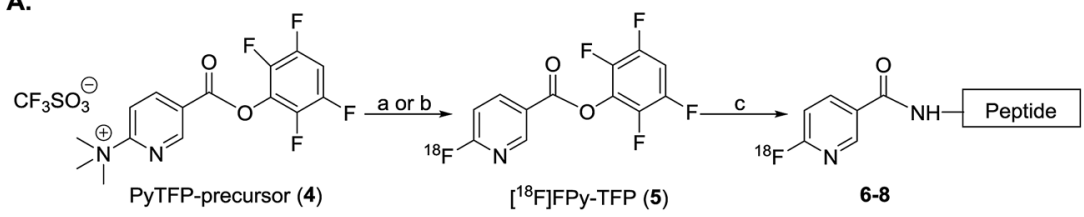<smiles>CC(C)C[C@H](NC(=O)[C@H](Cc1ccccc1)NC(=O)CNC(=O)CNC(=O)C(Cc1ccc(O)cc1)NC(=O)c1ccc(F)nc1)C(N)=O</smiles>

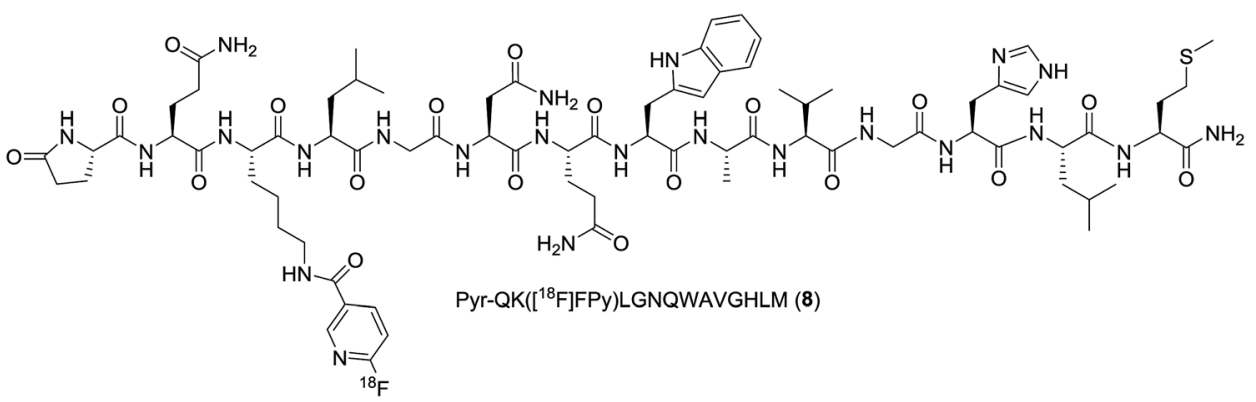

Scheme 1 (A) Radiolabeling of peptides with $\left[{ }^{18} \mathrm{~F}\right] \mathrm{FPy}-\mathrm{TFP}$ (5). (B) Structures of radiolabeled $\left[{ }^{18} \mathrm{~F}\right] \mathrm{FPy}$-peptides (6-8). Reagents and conditions: (a) $\left.{ }^{18} \mathrm{~F}\right] \mathrm{F}, \mathrm{K}_{222}, \mathrm{~K}_{2} \mathrm{CO}_{3}, 4: 1 \mathrm{tBuOH}: \mathrm{MeCN}, 40{ }^{\circ} \mathrm{C}, 10 \mathrm{~min}$ or (b) ${ }^{18}{ }^{18} \mathrm{FF}, \mathrm{TBA}-\mathrm{HCO}_{3}, 4: 1 \mathrm{tBuOH}: \mathrm{MeCN}, 40{ }^{\circ} \mathrm{C}, 10 \mathrm{~min}$. (c) Peptide (1 mg), DMSO, DIPEA, $40^{\circ} \mathrm{C}, 15 \mathrm{~min}$.

2.5/2.5, v/v/v, $1 \mathrm{~mL}, 3 \mathrm{~h}$ ) and purified by HPLC. The purified peptide $\left(\mathrm{NH}_{2}\right.$-YGGFL (1)) was characterized by HPLC and high resolution electrospray ionization mass spectrometry (HR-ESIMS) in positive mode on an Orbitrap (Thermo-Fisher Scientific, San Diego, CA, USA). The HPLC retention time was $7.48 \mathrm{~min}(\mathrm{~S} 9)$ and the HR-ESI-MS $m / z:[\mathrm{M}+\mathrm{H}]^{+}$calc'd for $\mathrm{C}_{28} \mathrm{H}_{39} \mathrm{~N}_{6} \mathrm{O}_{6}$ 555.2926; found 555.2906 (S10).

\section{${ }^{19}$ FPy-peptide reference standards}

${ }^{19}$ FPy-NH-YGGFL-CONH ${ }_{2}$. The ${ }^{19}$ FPy-YGGFL reference standard was prepared using peptidyl resin $(25 \mathrm{mg})$. The $N$-terminal Fmoc was removed by $20 \%$ piperidine in DMF $(2 \times 15 \mathrm{~min})$ and 6-fluoronicotinic acid $(10 \mathrm{mg})$ added via activation with HATU $(10 \mathrm{mg})$ and DIPEA $(25 \mu \mathrm{L})$ in DMF $(1 \mathrm{~mL})$. The peptidyl resin was allowed to react for $1.5 \mathrm{~h}$ before being rinsed with DMF $(3 \times)$ followed by methanol $(3 \times)$ and dried on the lyophilizer $(1 \mathrm{~h})$. The peptide was globally deprotected and cleaved from the resin with TFA/TIPS/ $\mathrm{H}_{2} \mathrm{O}(95 / 2.5 / 2.5, \mathrm{v} / \mathrm{v} / \mathrm{v}, 1 \mathrm{~mL}, 3 \mathrm{~h})$ and purified by HPLC and characterized by both HPLC and high resolution electrospray ionization mass spectrometry (HR-ESI-MS) in positive mode on an Orbitrap (Thermo-Fisher Scientific, San Diego, CA, USA). The retention time of $\left[{ }^{19} \mathrm{~F}\right]$ FPy-YGGFL-CONH ${ }_{2}$ was $9.52 \min (\mathrm{S} 11)$ and the HR-ESI-MS $m / z:[\mathrm{M}+\mathrm{H}]^{+}$calc'd for $\mathrm{C}_{34} \mathrm{H}_{41} \mathrm{FN}_{7} \mathrm{O}_{7} 678.3046$; found 678.3048 (S12).

CRGDyK $\left({ }^{19} \mathbf{F P y}\right)$. Following previously reported protocol,,${ }^{42}$ cRGDyK was synthesized and cyclized on resin preloaded with the aspartic acid (D), connected via its side-chain and protected as the allyl ester for orthogonal deprotection and cyclization. The sidechain $N \varepsilon$-amine of the lysine residue was protected with 1-(4,4-dimethyl-2,6-dioxocyclohex-1-ylidene)-3methylbutyl (ivDde) protecting group, that was removed with hydrazine after cyclization. The cRGDyK peptidyl resin was coupled with 6-fluoronicotinic acid $(10 \mathrm{mg})$ by reaction with HATU $(10 \mathrm{mg})$ and DIPEA $(50 \mu \mathrm{L})$ in DMF $(1 \mathrm{~mL})$ for $1.5 \mathrm{~h}$ and cleaved from the resin with TFA/TIPS/ $\mathrm{H}_{2} \mathrm{O}(95 / 2.5 / 2.5, \mathrm{v} / \mathrm{v} / \mathrm{v}, 1$ $\mathrm{mL}, 3 \mathrm{~h})$. The reference standard $\operatorname{cRGDyK}\left({ }^{19} \mathrm{FPy}\right)$ was HPLC purified and characterized by HPLC and high resolution electrospray ionization mass spectrometry (HR-ESI-MS) in positive mode on an Orbitrap (Thermo-Fisher Scientific, San Diego, CA, USA). The retention time of $\operatorname{cRGDyK}\left({ }^{19} \mathrm{FPy}\right)$ was $7.30 \mathrm{~min}(\mathrm{~S} 16)$ and the HR-ESI-MS $m / z:[\mathrm{M}+\mathrm{H}]^{+}$calc'd for $\mathrm{C}_{33} \mathrm{H}_{44} \mathrm{FN}_{10} \mathrm{O}_{9}$ 743.3271; found 743.3269 (S17).

Pyr-QK $\left({ }^{19}\right.$ FPy)LGNQWAVGHLM. The bombesin peptide (PyrQKLGNQWAVGHLM (3, Fig. 1), $0.25 \mathrm{mg}$ ) was reacted in solution DMF $(200 \mu \mathrm{L})$ with HATU $(5 \mathrm{mg})$, DIPEA $(25 \mu \mathrm{L})$, and 6-fluoronicotinic acid $(5 \mathrm{mg})$ for $2 \mathrm{~h}$. The peptide was then purified by 
HPLC and characterized by HPLC and matrix assisted laser desorption ionization time of flight mass spectrometry (MALDITOF-MS) with a matrix of sinapinic acid (Sigma Aldrich, St. Louis, MO, USA). The HPLC retention time of Pyr-QK $\left({ }^{19} \mathrm{FPy}\right)$ LGNQWAVGHLM was $8.40 \mathrm{~min}$ (S21) and the MALDI-TOF-MS $m / z:[\mathrm{M}+\mathrm{H}]^{+}$calc'd for $\mathrm{C}_{77} \mathrm{H}_{113} \mathrm{FN}_{23} \mathrm{O}_{19} \mathrm{~S}$ 1714.8282; found 1715.1168 (S22).

\section{Description of ELIXYS FLEX/CHEM® radiosynthesizer set up}

All radiosyntheses were carried out on an ELIXYS FLEX/CHEM ${ }^{\circledR}$ radiosynthesizer (Fig. 2). The ELIXYS FLEX/CHEM ${ }^{\circledR}$ radiosynthesizer has three identical, independent reactors that support heating and cooling (room temperature to $200{ }^{\circ} \mathrm{C}$ ) with stirring capabilities. The reactors move in the $Y, Z$-direction to engage with a universal disposable reagent cassette, which can hold up to 12 different reagents (36 for full system) of $3 \mathrm{~mL}$ volume in disposable septum sealed vials. The disposable cassette houses all reagents paths, and tubing assemblies for routing liquid, including two external addition ports, and an inlet for delivery of aqueous fluoride-18. Additionally, the underside of the cassette mates with the reactor v-vial at various positions for robot arm-assisted reagent addition (ADD REAGENT, 2 positions), gas and vacuum assisted evaporation (EVAPORATE, 1 position), fully-sealed reactions (REACT, 2 positions, supporting up to $150 \mathrm{psi}),{ }^{43}$ and transfer of contents out of the reactor $\mathrm{v}$-vial to various other positions in the synthesizer (TRANSFER, 1 position).

The reactor $\mathrm{v}$-vial is monitored at all times by a live camera feed displayed on the graphical user interface of the software. Likewise, radioactivity within the system is monitored by radiation sensors positioned throughout the system. The reagents, their location, and the cassettes used are listed in Table 1 for the automated peptide radiolabeling with $\left[{ }^{18} \mathrm{~F}\right]$ FPy-TFP (5). The synthesis program ("sequence"), consisting of individual "unit operations" wherein specific conditions (temp., inert gas pressure etc.) can be defined, was created for the synthesis of the $\left[{ }^{18} \mathrm{~F}\right]$ FPy-peptides (6-8) from $\left[{ }^{18} \mathrm{~F}\right]$ fluoride via conjugation with $\left[{ }^{18} \mathrm{~F}\right]$ FPy-TFP (5) (S1 $\left.\dagger\right)$. The ELIXYS radiosynthesizer was configured with two identical cassettes for each ${ }^{18} \mathrm{~F}$-peptide radiosynthesis that were connected via an external gross dilution vessel ( $25 \mathrm{~mL}$-pear shaped round bottom sealed with rubber septum) to enable the high volume dilution $(15 \mathrm{~mL})$ required for trapping of $\left[{ }^{18} \mathrm{~F}\right] \mathrm{FPy}$-TFP (5) on the SPE-cartridge. This dilution vessel was connected inline between reactors 1 and 2 and positioned before the purification MCX-cartridge. A small stir-plate was placed under the dilution vessel to enable stirring of the reaction mixture during the dilution step. The first cassette was joined from the "T" position on cassette 1 into the gross dilution vessel containing an outlet line composed of a long stainless steel syringe needle $(150 \mathrm{~mm})$ positioned at the bottom of the dilution flask leading out of the flask with the SPE-cartridge inline that feeds back into cassette 1 at the "C2-O" position, allowing for the dilution volume and SPE-washes to be directed to the waste. Cassette 1 was attached to cassette 2 from the "O" position of cassette 1 into the "I-1" position on cassette 2 .

\section{ELIXYS FLEX/CHEM ${ }^{\circledR}$ radiosynthesizer synthesis of $\left[{ }^{18}\right.$ F $]$ FPy- TFP (5) and radiolabeling of peptides}

Synthesis of $\left[{ }^{18}\right.$ F $]$ FPy-TFP (5). A solution of $\left[{ }^{18} \mathrm{~F}\right]$ fluoride in O18 water $(\sim 1$ to $2 \mathrm{~mL}, 6-10 \mathrm{mCi})$ was delivered into the system using 5 psi positive nitrogen gas pressure and trapped onto a $\mathrm{PS}-\mathrm{HCO}_{3}$ anion exchange cartridge. The radioactivity was eluted from the cartridge into reactor 1 with either (i) kryptofix $\left(\mathrm{K}_{222}, 20 \mathrm{mg}\right)$ and potassium carbonate $\left(\mathrm{K}_{2} \mathrm{CO}_{3}, 4 \mathrm{mg}\right)$ in $94: 6$ acetonitrile : water $\left(\mathrm{MeCN}: \mathrm{H}_{2} \mathrm{O}, 2 \mathrm{~mL}\right.$ ), or (ii) $0.075 \mathrm{M}$ tetrabutylammonium bicarbonate (TBA- $\mathrm{HCO}_{3}, 300 \mu \mathrm{L}, \mathrm{ABX}, \mathrm{GmBH}$, Radeburg, Germany) solution in 94:6 $\mathrm{MeCN}: \mathrm{H}_{2} \mathrm{O}(2 \mathrm{~mL})$ (reagent cassette 1 , position 1). After azeotropic drying with acetonitrile $(1 \mathrm{~mL} \times 2$, reagent cassette 1 , positions 2 and 3$)$ under vacuum and constant stirring, the precursor 4 (10 $\mathrm{mg}$,
A.

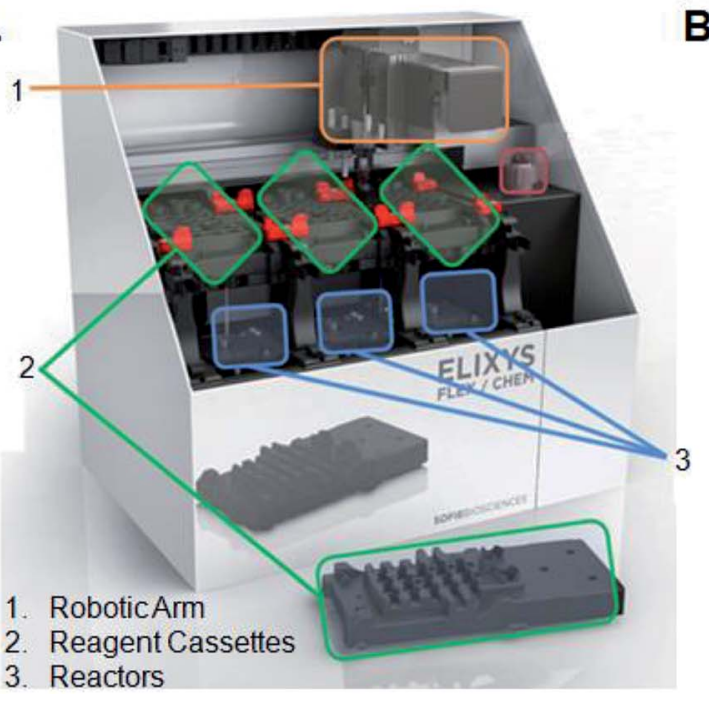

B.

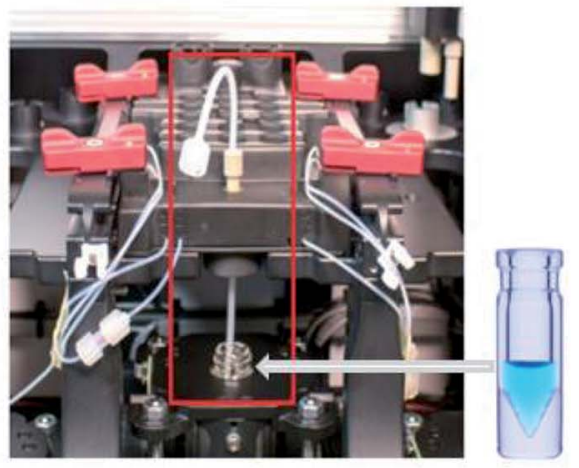

Fig. 2 (A) ELIXYS FLEX/CHEM® radiosynthesizer (B) zoom-in of a reagent cassette above one of the reactors containing the $v$-vial. 
Table 1 List of reagents in each reagent cassette of the ELIXYS FLEX/CHEM@ radiosynthesizer

\begin{tabular}{lll}
\hline Cassette \# & Reagent position & Reagent \\
\hline 1 & 1 & $\mathrm{~K}_{222} / \mathrm{K}_{2} \mathrm{CO}_{3}(20 \mathrm{mg} / 4 \mathrm{mg})$ in $94: 6 \mathrm{MeCN}: \mathrm{H}_{2} \mathrm{O}(2 \mathrm{~mL})^{a}$ \\
1 & 2 & $1.0 \mathrm{~mL} \mathrm{MeCN}$ \\
1 & 3 & $1.0 \mathrm{~mL} \mathrm{MeCN}$ \\
1 & 4 & {$\left[{ }^{18} \mathrm{~F}\right] \mathrm{Py}-\mathrm{TFP}$ precursor $(4,10 \mathrm{mg})$ in $4: 1 \mathrm{BuOH}: \mathrm{MeCN}(1 \mathrm{~mL})$} \\
1 & 5 & $2.5 \mathrm{~mL}$ water \\
1 & 6 & $2.5 \mathrm{~mL}$ water \\
1 & 7 & $3.0 \mathrm{~mL} \mathrm{MeCN}$ \\
2 & 1 & Peptide $(1 \mathrm{mg})$ in $0.5 \mathrm{~mL}$ DMSO and $10 \mu \mathrm{LL}$ DIPEA
\end{tabular}

${ }^{a}$ TBA- $\mathrm{HCO}_{3}(0.075 \mathrm{M}, 300 \mu \mathrm{L})$ in $94: 6 \mathrm{MeCN}: \mathrm{H}_{2} \mathrm{O}(2 \mathrm{~mL})$ was also used to elute fluoride-18 as another alternative with both methods providing identical results.

Scheme 1), dissolved in $4: 1 \mathrm{tBuOH}: \mathrm{MeCN}$ (1 mL) (reagent cassette 1 , position 4 ), was added to reactor 1 and heated to $40{ }^{\circ} \mathrm{C}$ for $10 \mathrm{~min}$ with constant stirring. After reaction completion, an aliquot (100-200 $\mu \mathrm{L})$ was taken out of the reaction, diluted to $1 \mathrm{~mL}$ with solvent $\mathrm{A}$ and the crude reaction mixture analyzed by analytical radio-HPLC (S6).

Purification of $\left[{ }^{18}\right.$ F $]$ FPy-TFP (5). After formation of $\left[{ }^{18} \mathrm{~F}\right] \mathrm{FPy}-$ TFP (5), the crude reaction mixture was transferred from reactor 1 into the dilution vessel, pre-loaded with $15 \mathrm{~mL}$ of water; the diluted mixture was then passed through an MCX SPE cartridge, trapping $\left[{ }^{18} \mathrm{~F}\right] \mathrm{FPy}-\mathrm{TFP}(5)$. The cartridge was then rinsed with water $(5 \mathrm{~mL}$, reagent cassette 1 , positions 5 and 6 ) by first adding water in 2 portions to reactor 1 , and then transferring it into the external dilution vessel and through the cartridge. Similarly, the $\left[{ }^{18} \mathrm{~F}\right] \mathrm{FPy}-\mathrm{TFP}(5)$ was eluted off the MCXcartridge with acetonitrile $(\mathrm{MeCN}, 3 \mathrm{~mL}$, reagent cassette 1 , position 7) (Fig. 3) into reactor 2, where the solvent was removed in preparation for peptide coupling. During method development, various preconditioned SPE-cartridges (C18 SepPak-Plus cartridge (Waters) and Oasis MCX-Plus cartridge (Waters) and their respective combinations) were explored for the purification of $\left[{ }^{18} \mathrm{~F}\right]$ FPy-TFP (5). The diluted crude $\left[{ }^{18} \mathrm{~F}\right] \mathrm{FPy}$-TFP (5) reaction mixture was trapped on four different SPE-cartridge combinations (MCX, C18SepPak, MCX-C18SepPak, and

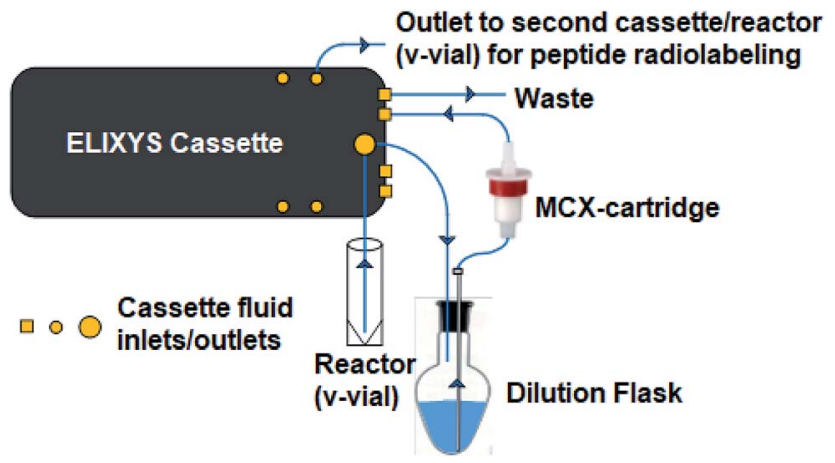

Fig. 3 Diagram of gross dilution set-up. Set-up allows $\left[{ }^{18} \mathrm{~F}\right] \mathrm{FPy}-\mathrm{TFP}(5)$ purification via a $15 \mathrm{~mL}$ water dilution in an external flask, trapping on an Oasis MCX cartridge followed by a $5 \mathrm{~mL}$ water wash and $3 \mathrm{~mL}$ acetonitrile elution. All operations are fully automated via ELIXYS FLEX/ $\mathrm{CHEM} \otimes$ radiosynthesizer and no manual interventions required.
C18SepPak-MCX), eluted in acetonitrile, analysed by analytical radioHPLC (S7) and identity confirmed by co-injection with ${ }^{19}$ FPy-TFP reference standard (S8). In each case, the SPEcartridges were positioned per Fig. 3.

Synthesis of $\left[{ }^{18}\right.$ F]FPy-peptides (6-8). Peptides ( $\mathrm{NH}_{2}$-YGGFL (1), cRGDyK (2), or Pyr-QKLGNQWAVGHLM (3), $1.0 \mathrm{mg}, 1.8$ $\mu \mathrm{mol}, 1.6 \mu \mathrm{mol}$, and $0.6 \mu \mathrm{mol}$ respectively, Fig. 1) were dissolved in $0.5 \mathrm{~mL}$ dimethylsulfoxide (DMSO) and DIPEA $(10 \mu \mathrm{L}$, reagent cassette 2, position 1) and added to the dried down MCXpurified $\left[{ }^{18} \mathrm{~F}\right]$ FPy-TFP $(5)$ in reactor 2 (Scheme 1). The reaction was heated at $40{ }^{\circ} \mathrm{C}$ for $15 \mathrm{~min}$ with constant stirring. The crude reaction mixture was diluted to $\sim 1.2 \mathrm{~mL}$ with solvent $\mathrm{A}$ and injected remotely onto an analytical radio-HPLC (S13, S18, and $\mathrm{S} 23)$. The purified radiolabeled peptide was collected, radioactivity measured, and then re-injected onto the analytical radioHPLC to assess overall yield and purity of final product (S14, S19 and S24). The molar activity was determined by injection of known amounts of each of the nonradioactive ${ }^{19} \mathrm{FPy}$-peptide reference standard and comparing the HPLC integration of the UV-peak $(220 \mathrm{~nm})$ to the associated UV-peak $(220 \mathrm{~nm})$ of the radioactive peak of the corresponding $\left[{ }^{18} \mathrm{~F}\right] \mathrm{FPy}$-peptide (6-8). The identity of all radiolabeled $\left[{ }^{18} \mathrm{~F}\right]$ FPy-peptides $(\mathbf{6}-\mathbf{8}$, Scheme 1) was confirmed by co-elution with non-radioactive ${ }^{19} \mathrm{FPy}$ peptide reference standards (S15, S20 and S25).

\section{Results}

\section{Synthesis of $\left[{ }^{18}\right.$ F]FPy-TFP (5) on ELIXYS FLEX/CHEM ${ }^{\circledR}$ radiosynthesizer}

$\left[{ }^{18} \mathrm{~F}\right]$ FPy-TFP (5) was generated in decay-corrected yields of 76.1 $\pm 3.5 \%(n=6)$ after MCX-cartridge purification with a synthesis time of $42 \pm 6$ minutes (Scheme 1). Radiofluorination utilized $10 \mathrm{mg}$ of the PyTFP-precursor (4), heated with $\left[{ }^{18} \mathrm{~F}\right]$ fluoride for 10 minutes at $40{ }^{\circ} \mathrm{C}$ in $t \mathrm{BuOH}: \mathrm{MeCN}(4: 1, \mathrm{v} / \mathrm{v})$. Purification was achieved using a single MCX-SPE-cartridge; an external gross dilution vessel was required to sufficiently dilute the crude reaction mixture prior to trapping on the SPE, however no manual intervention was required. Identical yields of $\left[{ }^{18} \mathrm{~F}\right] \mathrm{FPy}-$ TFP (5) were obtained using either $\mathrm{K}_{2.2 .2}\left(10 \mathrm{mg} \mathrm{mL}^{-1}\right)$ and $\mathrm{K}_{2} \mathrm{CO}_{3}\left(2 \mathrm{mg} \mathrm{mL}^{-1}\right)$ in a mixture of $\mathrm{MeCN}$ and $\mathrm{H}_{2} \mathrm{O}(94: 6, \mathrm{v} / \mathrm{v} ; 2$ $\mathrm{mL})$, or $\mathrm{TBAHCO}_{3}(300 \mu \mathrm{L}$ of a $0.075 \mathrm{M}$ solution $)$ in the same solvent system. 


\section{Purification of $\left[{ }^{18}\right.$ F $]$ FPy-TFP (5)}

Purification of $\left[{ }^{18} \mathrm{~F}\right]$ FPy-TFP (5) was required to remove excess unreacted PyTFP-precursor (4) and to limit formation of byproduct 2,3,5,6-tetrafluorophenyl-6-(2,3,5,6-tetrafluorophenoxy) nicotinate (11) (Fig. 4). ${ }^{38}$ Both PyTFP-precursor (4) and byproduct (11) can compete with $\left[{ }^{18} \mathrm{~F}\right] \mathrm{FPy}$-TFP (5) for peptide conjugation, hindering the radiochemical yield of $\left[{ }^{18} \mathrm{~F}\right] \mathrm{FPy}-$ peptides. The purification of $\left[{ }^{18} \mathrm{~F}\right] \mathrm{FPy}$-TFP (5) was explored using various SPE cartridge(s) (C18 SepPak-Plus cartridge, Oasis MCX-Plus cartridge, and combinations of the two) by monitoring UV impurities by HPLC. The crude HPLC-chromatogram of the $\left[{ }^{18} \mathrm{~F}\right]$ FPy-TFP (5, Fig. 5A, peak $\left.\boldsymbol{\Delta}\right)$ showed large amounts of unreacted PyTFP-precursor (4, Fig. 5A, peak *), along with 2,3,5,6-tetrafluorophenol (9, Fig. 5B, peak $\boldsymbol{\square}$ ), no by-product (11) was observed as previously by Olberg et al. ${ }^{38}$ Purification via MCX-cartridge removed excess PyTFP-precursor (4) (Fig. 5B), with the only remaining impurity being the UV-impurity of 2,3,5,6-tetrafluorophenol (9, Fig. 5B, peak $\square$ ). Further attempts to improve the purification using combinations of C18 SepPakPlus and Oasis MCX-Plus cartridges in series, did not afford higher purities than the MCX-cartridge alone. In fact, all dualcartridge purification systems examined, led to a higher percentage of hydrolysis of $\left[{ }^{18} \mathrm{~F}\right] \mathrm{FPy}-\mathrm{TFP}(5$, Fig. 5C, peak $\boldsymbol{\Delta})$, as demonstrated by increased amounts of $6-\left[{ }^{18} \mathrm{~F}\right]$ fluoronicotinic acid (Fig. 5C, peak $\bigcirc$ ). In summary, a single Oasis MCX-Plus cartridge provided the optimal purification and had the best elution efficiencies $(>80 \%)$ with minimal hydrolysis of $\left[{ }^{18} \mathrm{~F}\right] \mathrm{FPy}-$ TFP (5) to 6- $\left[{ }^{18} \mathrm{~F}\right]$ fluoronicotinic acid.

\section{Synthesis of $\left[{ }^{18}\right.$ F]FPy-peptides (6-8) via ELIXYS FLEX/CHEM® radiosynthesizer}

Coupling of peptides (1-3, Fig. 1) to purified $\left[{ }^{18}\right.$ F $]$ FPy-TFP (5) was achieved via reaction with $1 \mathrm{mg}$ of peptide in $0.5 \mathrm{~mL}$ DMSO and $10 \mu \mathrm{L}$ of DIPEA at $40{ }^{\circ} \mathrm{C}$ for $15 \mathrm{~min}$. Purified $\left[{ }^{18} \mathrm{~F}\right] \mathrm{FPy}-$ peptides (6-8, Scheme 1) were obtained from $\left[{ }^{18} \mathrm{~F}\right]$ fluoride in a total synthesis time of $97 \pm 3$ minutes, and with decay corrected yields (including 25 min HPLC purification) ranging between 13-26\% $(n=4)$. Radiochemical purities were high (>99\%, Table 2), and molar activities ranged from 1-5 Ci $\mu_{\mathrm{mol}}{ }^{-1}$. The crude radioHPLC chromatogram for each peptide (S13, S18 and S23) showed only two radiochemical peaks, corresponding to the radiolabeled $\left[{ }^{18} \mathrm{~F}\right] \mathrm{FPy}$-peptide (Fig. 6A, peak $\bullet$ and hydrolyzed $\left[{ }^{18} \mathrm{~F}\right]$ FPy-TFP (5) to $6-\left[{ }^{18} \mathrm{~F}\right]$ fluoronicotinic acid (Fig. 6A, peak $)$ ). Fig. 6B is a representative HPLC chromatogram of purified radiolabeled $\left[{ }^{18} \mathrm{~F}\right] \mathrm{FPy}$-YGGFL (6) peptide's co-injected with its ${ }^{19}$ FPy-YGGFL peptide reference standard (S15, S20, and S25), showing that all radiolabeled peptides could be purified to $>99 \%$ radiochemical purity.

\section{Discussion}

The unique properties of receptor-targeting peptides, such as their high target affinity, rapid clearance from the circulation, and relative ease of synthesis, has made them attractive agents for both receptor imaging and targeted radiotherapy., ${ }^{3,4}$ With favorable nuclear and physiochemical characteristics, ${ }^{18} \mathrm{~F}$ radiolabeled receptor-targeting peptides have shown great promise as imaging agents in oncology. However, there remains an unmet need to develop a reliable, reproducible, fully automated approach that is amenable to cGMP guidelines and can be applied to a wide range of peptides. ${ }^{4}$ Therefore, the goal of this work was to develop a fully automated radiolabeling protocol to generate ${ }^{18} \mathrm{~F}$-peptides from $\left[{ }^{18} \mathrm{~F}\right]$ fluoride requiring no manual user interventions, using $\left[{ }^{18} \mathrm{~F}\right] \mathrm{FPy}$-TFP and the ELIXYS FLEX/CHEM® radiosynthesizer.

The $\left[{ }^{18} \mathrm{~F}\right] \mathrm{FPy}$-TFP prosthetic group is an activated ester prepared in a single step from $\left[{ }^{18} \mathrm{~F}\right]$ fluoride with a single cartridge based purification, and can be coupled to any peptide bearing a free amine, either at the $N$-terminus or at the $N \varepsilon$ on a lysine residue in the peptide sequence. ${ }^{38}$ To date, the batch production of $\left[{ }^{18} \mathrm{~F}\right] \mathrm{FPy}$-TFP and subsequent peptide radiolabeling has been carried out using manual synthesis techniques. ${ }^{38,44-46}$ Although Olberg, Malik, and others have demonstrated the effectiveness of the $\left[{ }^{18} \mathrm{~F}\right] \mathrm{FPy}$-TFP prosthetic group for radiolabelling various peptides, intermediate purification of the $\left[{ }^{18} \mathrm{~F}\right] \mathrm{FPy}$-TFP was required prior to conjugation to a peptide in order to remove unreacted PyTFP-precursor that interferes with peptide radiolabeling. ${ }^{38,44-46}$ In addition, Olberg et al. showed that hydrolysis of the PyTFP-precursor resulted in formation of 2,3,5,6-tetrafluorophenyl-6-(2,3,5,6tetrafluorophenoxy)nicotinate (by-product (11)), which can hinder efficient radiolabeling of the peptide. ${ }^{38}$ To facilitate purification, the ELIXYS FLEX/CHEM ${ }^{\circledR}$ radiosynthesizer can

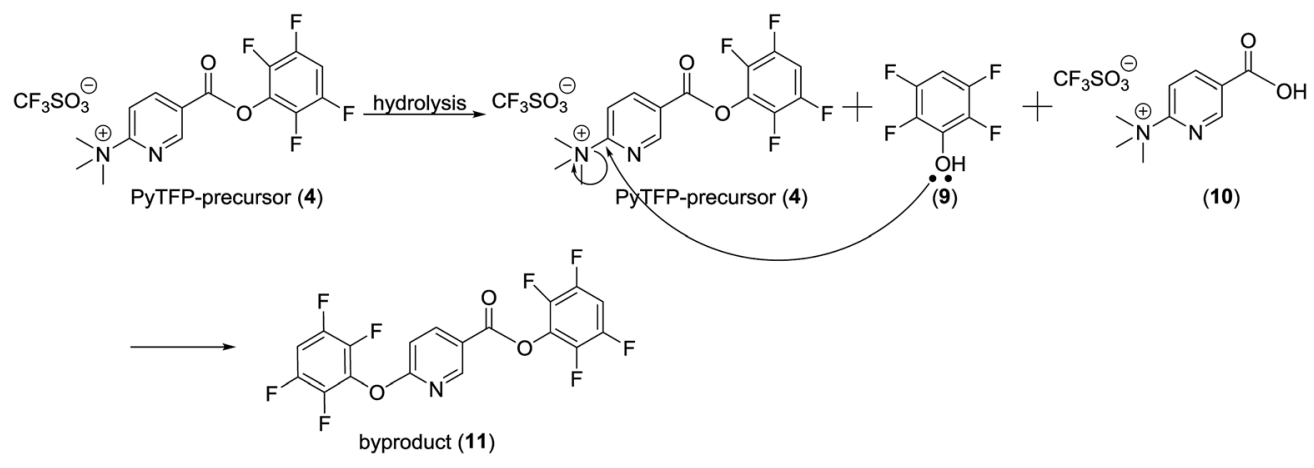

Fig. 4 Mechanism for by-product (11) formation during $\left[{ }^{18} \mathrm{~F}\right] F P y-T F P(5)$ synthesis. 
A.

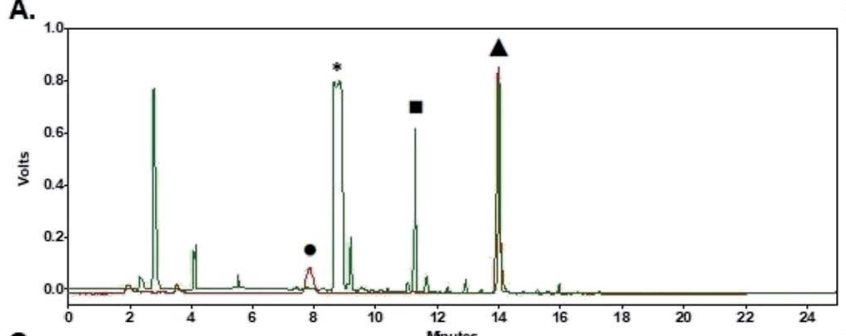

c.

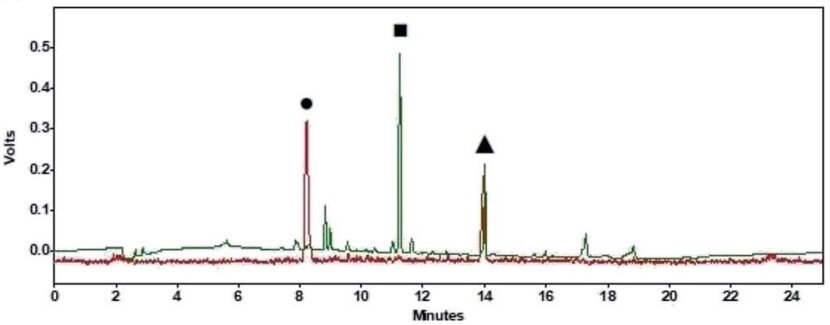

B.

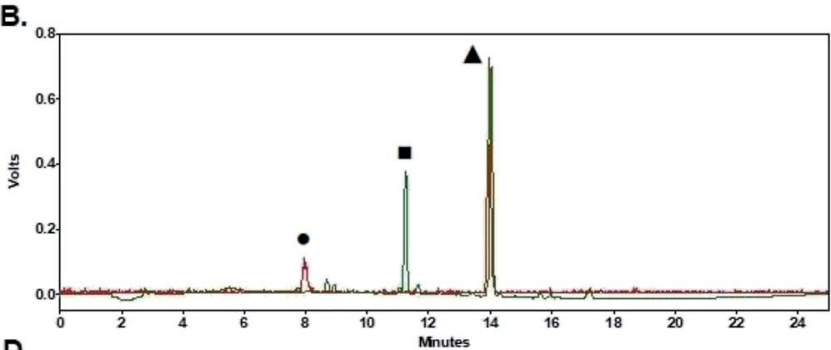

D.

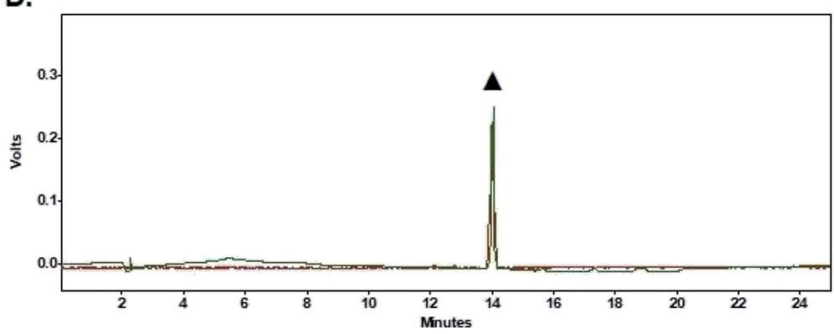

Fig. $5 \quad\left[{ }^{18}\right.$ F]FPy-TFP (5) HPLC-chromatograms (PMT (gamma)-red, UV (220 nm)-green). (A) Crude HPLC chromatogram (peak $\bullet-6-\left[{ }^{18}\right.$ F]fluoronicotinic acid, peak *-PyTFP-precursor (4), peak -2,3,5,6-tetrafluorophenol (9), peak $\left.\boldsymbol{\Delta}-{ }^{18} \mathrm{~F}\right] \mathrm{aPy}$-TFP (5)). (B) HPLC chromatogram after MCX-cartridge purification (peak -6- $\left[{ }^{18}\right.$ F]fluoronicotinic acid, peak -2,3,5,6-tetrafluorophenol (9), peak $\mathbf{\Delta}-\left[{ }^{18} \mathrm{~F}\right] \mathrm{FPy}$-TFP (5)). (C) HPLC chromatogram after MCX-C18SepPak double cartridge purification (peak -6- $\left[{ }^{18}\right.$ F]fluoronicotinic acid, peak $\mathbf{\square}-2,3,5,6$-tetrafluorophenol (9), peak $\boldsymbol{\Delta}-\left[{ }^{18} \mathrm{~F}\right] \mathrm{FPy}$-TFP (5)). (D) Purified HPLC-chromatogram co-injected with $\left[{ }^{19} \mathrm{~F}\right] \mathrm{FPy}$-TFP (peak $\boldsymbol{\Delta}-\left[{ }^{18} \mathrm{~F}\right] \mathrm{FPyTFP}(5)$ ).

Table 2 Summary of $\left[{ }^{18} \mathrm{~F}\right]$ Py-TFP (5) radiolabeling yields of peptides (1-3)

\begin{tabular}{llll}
\hline Peptide & Amount & \% Yield $^{a}$ & $\begin{array}{l}\text { Radiochemical } \\
\text { purity }\end{array}$ \\
\hline 6 & $1.0 \mathrm{mg}, 1.8 \mu \mathrm{mol}$ & $25.6 \pm 2.7$ & $>99 \%$ \\
7 & $1.0 \mathrm{mg}, 1.6 \mu \mathrm{mol}$ & $16.0 \pm 5.6$ & $>99 \%$ \\
8 & $1.0 \mathrm{mg}, 0.6 \mu \mathrm{mol}$ & $13.0 \pm 5.2$ & $>99 \%$
\end{tabular}

${ }^{a}$ Radiochemical decay corrected yields from $\left[{ }^{18} \mathrm{~F}\right]$ fluoride of purified radiolabeled peptide reported as the average yield $\pm \mathrm{SD}(n=4)$.

accommodate SPE-cartridges in multiple configurations, enabling intermediate cartridge based purifications within the reaction sequence. However, in order to purify $\left[{ }^{18} \mathrm{~F}\right] \mathrm{FPy}-\mathrm{TFP}$, the initial organic reaction mixture required dilution with $15 \mathrm{~mL}$ water prior to trapping on the SPE-cartridge. To achieve this a pre-filled external vessel was incorporated upstream of the Oasis MCX-SPE-cartridge, with minimal modifications to the ELIXYS FLEX/CHEM ${ }^{\circledR}$ radiosynthesizer system. As a result, $\left[{ }^{18} \mathrm{~F}\right]$ FPy-TFP was produced with average yields of $76.1 \pm 3.5 \%$ and sufficiently high radiochemical and chemical purities. These yields are comparable to other automated ${ }^{18} \mathrm{~F}$-prosthetics group productions used for peptide radiolabeling. For example, the automated synthesis of $\left[{ }^{18} \mathrm{~F}\right] \mathrm{FBEM}$ on an Eckert \& Ziegler module took 95 minutes to afford a $17.3 \pm 7.1 \%$ non-decay corrected yield. ${ }^{47}$ The automated synthesis of $\left[{ }^{18} \mathrm{~F}\right] \mathrm{SFB}$ on a TRACERlab $\mathrm{FX}_{\mathrm{FN}}$ synthesizer (GE Healthcare) produced nondecay corrected yields ranging from $25-35 \%$ in 40 minutes. ${ }^{48}$ Thonon, et al. also automated the synthesis of $\left[{ }^{18} \mathrm{~F}\right] \mathrm{SFB}$ to yield $42 \%$ decay corrected yield in 57 minutes on a FASTLab ${ }^{\mathrm{TM}}(\mathrm{GE}$ Healthcare). ${ }^{36}$ Other ${ }^{18} \mathrm{~F}$-prosthetics such as $\left[{ }^{18} \mathrm{~F}\right]$ FBEM, $\left[{ }^{18} \mathrm{~F}\right]$ $\mathrm{SFB}$, and $\left[{ }^{18} \mathrm{~F}\right] \mathrm{F}-\mathrm{TCO}$ were previously produced with decay corrected yields of $35 \pm 8 \%$ (98 $\mathrm{min}), 69 \pm 8 \%$ (78 $\mathrm{min})$, and 44 $\pm 9 \%(71 \mathrm{~min})$ respectively, using the ELIXYS FLEX/CHEM ${ }^{\circledR}$ radiosynthesizer. ${ }^{32}$

Radiolabeling of peptides with $\left[{ }^{18} \mathrm{~F}\right] \mathrm{FPy}$-TFP were previously performed manually using a variety of peptide coupling conditions. ${ }^{38,44-46}$ The original manual peptide radiolabeling with $\left[{ }^{18} \mathrm{~F}\right]$ FPy-TFP by Olberg et al. utilized a $1: 1: 1$ DMSO : MeCN : phosphate buffer (pH-9.0), 3-5 mg of peptide, and a reaction temperature of $40{ }^{\circ} \mathrm{C}$ for 15 minutes to generate the $\left[{ }^{18} \mathrm{~F}\right] \mathrm{FPy}$-peptide in a $22.5 \pm 6.0 \%$ yield (total synthesis time $=85$ minutes). ${ }^{38}$ Malik et al. manually radiolabeled a DUPApeptide $(2 \mathrm{mg})$ with $\left[{ }^{18} \mathrm{~F}\right] \mathrm{FPy}$-TFP in $5: 3 \mathrm{MeCN}: \mathrm{H}_{2} \mathrm{O}$, containing $5.5 \mathrm{mg}$ of sodium bicarbonate as a base, at $60{ }^{\circ} \mathrm{C}$ for 10 minutes, resulting in a $48 \pm 0.9 \%$ non-decay corrected yield (total synthesis time $=50$ minutes). ${ }^{44}$ Basuli et al. manually reacted 3-5 mg of peptide at $50{ }^{\circ} \mathrm{C}$ for 10 minutes with $\left[{ }^{18} \mathrm{~F}\right] \mathrm{FPy}-$ TFP in a $2.75: 2.5: 1$ mixture of $\mathrm{MeCN}: \mathrm{H}_{2} \mathrm{O}: t \mathrm{BuOH}$ containing either $10-15 \mathrm{mg}$ of sodium bicarbonate or $5 \mu \mathrm{L}$ of triethylamine, generating the ${ }^{18} \mathrm{~F}$-peptide in non-decay corrected yields of $25-43 \%$ (total synthesis time $=30$ minutes). ${ }^{45,46}$ To avoid solubility issues and the potential to clog lines and needles of the automated system, DIPEA was used over sodium bicarbonate as the base. DMSO was selected as a solvent, as previous literature suggested that peptide conjugation in buffers seemed to result in lower yields. ${ }^{36}$ Using these conditions, acceptable radiochemical yields (13-26\%) were achieved using minimal amounts of peptide $(1 \mathrm{mg})$.

The radiolabeling yields for YGGFL using the ELIXYS FLEX/ CHEM ${ }^{\circledR}$ radiosynthesizer were $25.6 \pm 2.7 \%$ and were comparable to the previously reported radiolabeling yield of YGGFL with $\left[{ }^{18} \mathrm{~F}\right]$ FPy-TFP using the Advion NanoTek microfluidic device, which produced a $26 \%$ incorporation yield in 12 minutes. ${ }^{49}$ However, the microfluidics device could not readily 


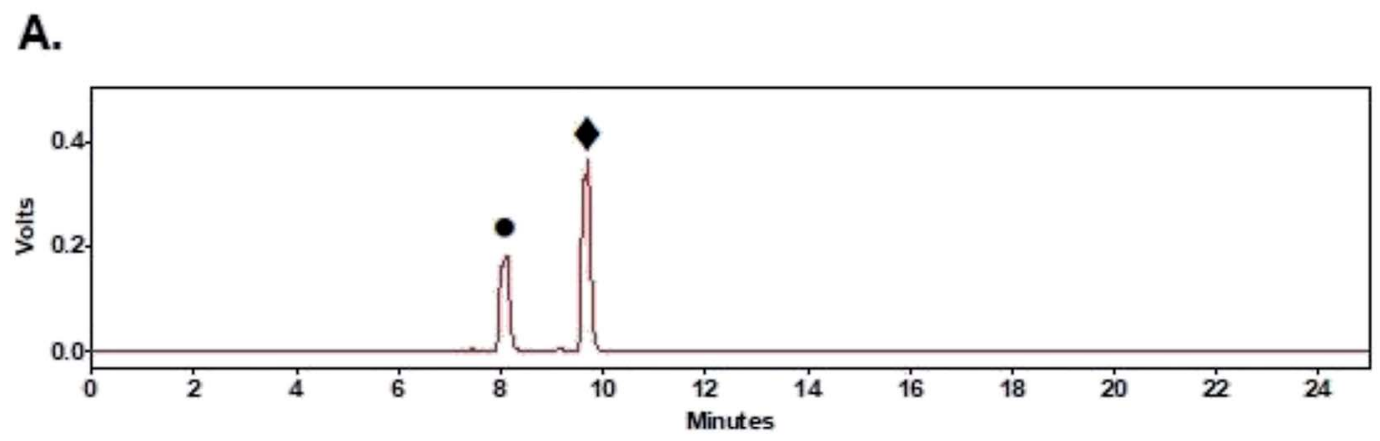

B.

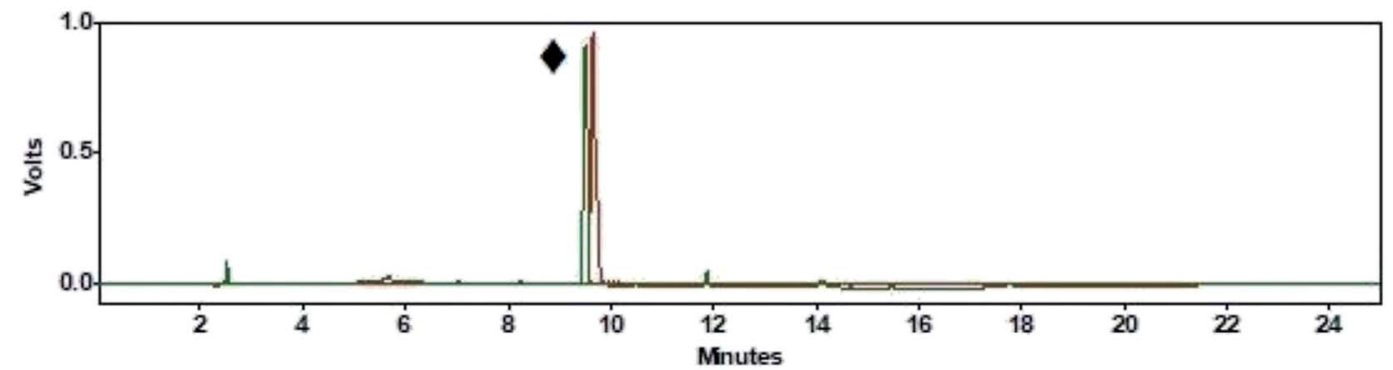

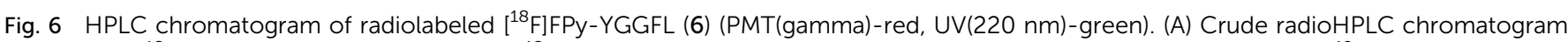
(peak - -6- $\left[{ }^{18}\right.$ F fluoronicotinic acid, peak $\left.\bullet-\left[{ }^{18} \mathrm{~F}\right] F P y-Y G G F L(6)\right)$. (B) Purified HPLC chromatogram co-injected with $\left.{ }^{19} \mathrm{~F}\right] F P y-Y G G F L$ (peak $\diamond-\left[{ }^{18}\right.$ F]FPy-YGGFL (6)).

be used to produce "batch" amounts of $\left[{ }^{18} \mathrm{~F}\right] \mathrm{FPy}$-peptides due to practical limitations to scaling up, such as volume and radiation shielding restrictions. The radiolabeling of cRGDyK using the ELIXYS FLEX/CHEM ${ }^{\circledR}$ radiosynthesizer yielded $\operatorname{cRGDyK}\left(\left[{ }^{18} \mathrm{~F}\right] \mathrm{FPy}\right)$ in $16.0 \pm 5.6 \%$ using $1.6 \mu \mathrm{mol}$ of peptide. Manual radiolabelings of cRGDfK with $\left[{ }^{18} \mathrm{~F}\right] \mathrm{FPy}$-TFP by Basuli, et al. afforded an non-decay corrected yields of $32-43 \%$ in a total of 30 minutes, but required 3-5 times the amount of peptide. ${ }^{46}$ Other manual approaches for radiolabeling various cRGDpeptides with fluorine-18 have provided yields between 10$35 \%$ with total reaction times ranging between 90-218 minutes. ${ }^{50-55}$ The yield obtained for cRGDyK $\left(\left[{ }^{18} \mathrm{~F}\right] \mathrm{FPy}\right)$ was also similar to the previously reported manual solid phase radiolabeling of cRGDyK with $6-\left[{ }^{18} \mathrm{~F}\right]$ fluorobenzoic acid $(14 \pm 2 \%$ yield in 90 minutes). ${ }^{42}$ Overall, using the ELIXYS FLEX/CHEM ${ }^{\circledR}$ radiosynthesizer was faster, with a total synthesis time under a 100 minutes including HPLC purification, and provided similar radiochemical yields.

The radiolabeling yields for $\left[{ }^{18} \mathrm{~F}\right] \mathrm{FPy}$-bombesin using the ELIXYS FLEX/CHEM ${ }^{\circledR}$ were $13.0 \pm 5.2 \%$. Other reports describing the synthesis of radiolabeled bombesin analogues have predominantly used radiometals $\left({ }^{64} \mathrm{Cu},{ }^{68} \mathrm{Ga}\right.$, and $\left.{ }^{111} \mathrm{In}\right)$ and chelation chemistry, with only a handful describing the manual synthesis of ${ }^{18} \mathrm{~F}$-bombesin analogues. ${ }^{56-58}$ For example, Lys ${ }^{3}$-bombesin, was radiolabeled using $4-\left[{ }^{18} \mathrm{~F}\right]$ fluoroazidobutane in a strain promoted copper free 1,3-dipolar cyclization reaction which proceeded at room temperature in 15 minutes to give a $37 \%$ radiochemical yield. ${ }^{56}$ Zhang et al. reported the radiolabelling of Lys ${ }^{3}$-bombesin using $\left[{ }^{18} \mathrm{~F}\right] \mathrm{SFB}$ in sodium borate buffer $(\mathrm{pH}=8.5)$ at $40{ }^{\circ} \mathrm{C}$ for 30 minutes, to produce radiochemical yields of $31.4 \pm 4.6 \%$ with a total synthesis time of $150 \pm 20$ minutes from fluorine-18. ${ }^{57}$ Most recently, a kit-radiolabeling approach of a bombesin derivative with $\left[{ }^{18} \mathrm{~F}\right]$-NOTA-AlF afforded $50-60 \%$ radiochemical yields, but required a high temperature of $95^{\circ} \mathrm{C} . .^{58}$ The previously reported ${ }^{18} \mathrm{~F}$-radiolabelings of bombesin have produced higher yields than the presented automated $\left[{ }^{18} \mathrm{~F}\right] \mathrm{FPy}$-TFP radiolabeling of bombesin using various radiochemical approaches. The most similar method used was the manual two-step indirect radiolabeling approach utilizing a different activated ester $\left[{ }^{18} \mathrm{~F}\right] \mathrm{SFB} .{ }^{57}$ This manual $\left[{ }^{18} \mathrm{~F}\right] \mathrm{SFB}$ radiolabeling of bombesin ${ }^{57}$ employed a different reaction solvent, concentration, and a reaction time of 30 minutes, double that of $\left[{ }^{18} \mathrm{~F}\right]$ FPy-TFP.

Several groups have attempted to develop automated protocols for the production of ${ }^{18} \mathrm{~F}$-labeled peptides. One of the most complete examples reported to date by Thonon et al., used the FASTLab (GE Healthcare) to produce $\left[{ }^{18} \mathrm{~F}\right] \mathrm{SFB}$ via both a oneand two-pot method, followed by coupling to an RGD peptide (PRGD2). ${ }^{36}$ Higher yields and fewer by-products were observed with the 2-pot approach, which generated $\left[{ }^{18} \mathrm{~F}\right] \mathrm{PRGD} 2$ in decaycorrected yields of $13 \pm 3 \%$ after 130 minutes with high radiochemical purity $(>98 \%)$ and high molar activity $(3873 \pm$ $1081 \mathrm{Ci} \mathrm{mmol}{ }^{-1}$ ). This semi-automated method included a single manual intervention; the addition of the peptide to the FASTLab module. ${ }^{36}$ Tang et al. also carried out a semiautomated synthesis wherein $\left[{ }^{18} \mathrm{~F}\right] \mathrm{SFB}$ was produced on a TRACERlab $\mathrm{FX}_{\mathrm{FN}}$ synthesizer (GE Healthcare) and then manually coupled to a cell penetrating peptide in a 30 minutes reaction to afford a $10-20 \%$ non-decay corrected yields of $\left[{ }^{18} \mathrm{~F}\right]$ SFB-peptide. ${ }^{48}$ Valdivia et al. generated the $\left[{ }^{18} \mathrm{~F}\right] \mathrm{F}$-pyridyl alkyne 
prosthetic $\left[{ }^{18} \mathrm{~F}\right] \mathrm{FPyKYNE}$ and subsequently coupled it to cRGDyK using a TRACERLab $\mathrm{FX}_{\mathrm{FN}}$ pro module. ${ }^{59}$ Following HPLC-purification, the radiolabeled peptide was obtained in $12-18 \%$ decay-corrected yields in 125 minutes with high radiochemical purities (>99\%) and specific activities (980-2000 $\left.\mathrm{Ci} \mathrm{mmol}^{-1}\right){ }^{59}$ This report, however, uses copper-mediated prosthetic coupling, which may not be suitable for all applications and due to the reagent's high toxicity additional purification maybe required to ensure copper levels are below the FDA ICH Q3D guidelines. Recently, Inkster et al. introduced a thiol-targeted $\left[{ }^{18} \mathrm{~F}\right]$ fluoro-2-cyanobenzothiazole prosthetic, which was subsequently coupled to a cysteine-functionalized cRGDfK peptide using a TRACERLab $\mathrm{FX}_{\mathrm{FN}}$ pro module. ${ }^{60}$ Moderate decay-corrected yields of $7 \pm 1 \%$ were reported after 124-132 minutes, along with high radiochemical purities and reasonable specific activities $\left(\sim 100\right.$ to $\left.300 \mathrm{Ci} \mathrm{mmol}{ }^{-1}\right) .{ }^{60}$ Overall, ELIXYS FLEX/CHEM ${ }^{\circledR}$ radiosynthesizer radiolabelings produced similar yields within the same timeframe.

\section{Conclusions}

The ELIXYS FLEX/CHEM $®$ radiosynthesizer was specifically designed to support good manufacturing practices (i.e. disposable cassettes, software with detailed batch record keeping, etc.) for ${ }^{18} \mathrm{~F}$-radiolabeled compounds, ultimately enabling their rapid translation into the clinic. Until now the fully automated synthesis of ${ }^{18} \mathrm{~F}$-peptides from fluorine- 18 has been challenging in part due to the complexity of synthesis and purification of both the intermediate prosthetic and the final ${ }^{18} \mathrm{~F}$-peptide. This work represents the fully automated batch production of three $\left[{ }^{18} \mathrm{~F}\right]$ FPy-peptides in a two-step approach from fluorine-18 using the ELIXYS FLEX/CHEM $®$ radiosynthesizer. Minimal amounts of peptide were required to achieve good radiochemical yields $13-26 \%$ with high molar activities $1-5 \mathrm{Ci}_{\mu} \mathrm{mol}^{-1}$ and radiochemical purity $>99 \%$. In the future addition of the ELIXYS PURE/FORM $®$, a HPLC purification module that interfaces with the ELIXYS FLEX/CHEM ${ }^{\circledR}$ radiosynthesizer will enable the whole process to be fully automated.

\section{Conflicts of interest}

Drs Drake and Moore are employees and owners of SOFIE Co.

\section{Acknowledgements}

This work was supported by the Office of Science, United States Department of Energy: (DE-SC0008385). Additional support for C. R. D. and M. M. was received from the National Cancer Institute (HHSN261201400041C), National Institute of Mental Health (2R44MH097271), and National Institute of Biomedical Imaging and Bioengineering (1R43EB023782-01).

\section{References}

1 A. A. Kaspar and J. M. Reichert, Future directions for peptide therapeutics development, Drug Discovery Today, 2013, 18(17), 807-817.
2 K. Fosgerau and T. Hoffmann, Peptide therapeutics: current status and future directions, Drug Discovery Today, 2015, 20(1), 122-128.

3 M. Fani, H. R. Maecke and S. M. Okarvi, Radiolabeled peptides: Valuable tools for the detection and treatment of cancer, Theranostics, 2012, 2(5), 481-501.

4 S. Richter and F. Wuest, ${ }^{18} \mathrm{~F}$-Labeled peptides: The future is bright, Molecules, 2014, 19(12), 20536-20556.

5 L. Y. Hu, K. A. Kelly and J. L. Sutcliffe, High-throughput approaches to the development of molecular imaging agents, Mol. Imaging Biol., 2017, 19(2), 163-182.

6 C. B. Johnbeck, U. Knigge and A. Kjaer, PET tracers for somatostatin receptor imaging of neuroendocrine tumors: current status and review of the literature, Future Oncol., 2014, 10(14), 2259-2277.

7 M. W. Hanson, Scintigraphic evaluation of neuroendocrine tumors for applied radiology, Appl. Radiol., 2001, 30(6), 1117.

8 W. A. Weber, Positron emission tomography as an imaging biomarker, J. Clin. Oncol., 2006, 24(10), 3282-3292.

9 P. Laverman, et al. A novel facile method of labeling octreotide with ${ }^{18}$ F-fluorine, J. Nucl. Med., 2010, 51(3), 454461.

10 M. Gabriel, et al. ${ }^{68}$ Ga-DOTA-Tyr ${ }^{3}$-octreotide PET in neuroendocrine tumors: Comparison with somatostatin receptor scintigraphy and CT, J. Nucl. Med., 2007, 48(4), 508-518.

11 I. Velikyan, Prospective of ${ }^{68}$ Ga-radiopharmaceutical development, Theranostics, 2013, 4(1), 47-80.

$12 \mathrm{M}$. Barrio, et al. The Impact of somatostatin receptordirected PET/CT on the management of patients with neuroendocrine tumor: A systematic review and metaanalysis, J. Nucl. Med., 2017, 58(5), 756-761.

13 R. Haubner, D. Finsinger and H. Kessler, Stereoisomeric peptide libraries and peptidomimetics for designing selective inhibitors of the $\alpha_{\mathrm{v}} \beta_{3}$ integrin for a new cancer therapy, Angew. Chem., Int. Ed., 1997, 36(13-14), 1374-1389.

14 F. Danhier, A. Le Breton and V. Préat, RGD-Based strategies to target $\alpha_{v} \beta_{3}$ integrin in cancer therapy and diagnosis, Mol. Pharmaceutics, 2012, 9(11), 2961-2973.

15 J. S. Desgrosellier and D. A. Cheresh, Integrins in cancer: biological implications and therapeutic opportunities, Nat. Rev. Cancer, 2010, 10(1), 9-22.

16 E. Ruoslahti and M. D. Pierschbacher, New perspectives in cell adhesion: RGD and integrins, Science, 1987, 238(4826), 491-497.

17 R. Haubner and C. Decristoforo, Radiolabelled RGD peptides and peptidomimetics for tumour targeting, Front. Biosci., Landmark Ed., 2009, 14, 872-886.

18 R. Haubner, S. Maschauer and O. Prante, PET radiopharmaceuticals for imaging integrin expression: Tracers in clinical studies and recent developments, BioMed Res. Int., 2014, 2014, 1-17.

19 F. C. Gaertner, et al. Radiolabelled RGD peptides for imaging and therapy, Eur. J. Nucl. Med. Mol. Imaging, 2012, 39(1), 126138. 
20 A. Bandyopadhyay and S. Raghavan, Defining the role of integrin alpha(v)beta(6) in cancer, Curr. Drug Targets, 2009, 10(7), 645-652.

21 B. J. Hackel, et al. ${ }^{18}$ F-Fluorobenzoate-labeled cystine knot peptides for PET imaging of integrin alpha(v)beta(6), $J$. Nucl. Med., 2013, 54(7), 1101-1105.

$22 \mathrm{~S}$. Li, et al. Synthesis and characterization of a high-affinity alpha(v)beta(6)-specific ligand for in vitro and in vivo applications, Mol. Cancer Ther., 2009, 8(5), 1239-1249.

23 M. K. J. Gagnon, et al. High-throughput in vivo screening of targeted molecular imaging agents, Proc. Natl. Acad. Sci. U. S. A., 2009, 106(42), 17904-17909.

24 S. H. Hausner, et al. Targeted in vivo imaging of integrin $\alpha_{v} \beta_{6}$ with an improved radiotracer and its relevance in a pancreatic tumor model, Cancer Res., 2009, 69(14), 58435850 .

25 S. H. Hausner, et al. The effect of bi-terminal PEGylation of an integrin $\alpha_{\mathrm{v}} \beta_{6}$-targeted ${ }^{18} \mathrm{~F}$ peptide on pharmacokinetics and tumor uptake, J. Nucl. Med., 2015, 56(5), 784-790.

26 S. H. Hausner, et al. Preclinical development and first-in human imaging of integrin $\alpha_{v} \beta_{6}$ with $\left[{ }^{18} \mathrm{~F}\right] \alpha_{\mathrm{v}} \beta_{6}$-binding peptide in metastatic carcinoma, Clin. Cancer Res., 2019, 25(4), 1206-1215.

27 A. A. Begum, P. M. Moyle and I. Toth, Investigation of bombesin peptide as a targeting ligand for the gastrin releasing peptide (GRP) receptor, Bioorg. Med. Chem., 2016, 24(22), 5834-5841.

$28 \mathrm{Y}$. Zilin, et al. An update of radiolabeled bombesin analogs for gastrin-releasing peptide receptor targeting, Curr. Pharm. Des., 2013, 19(18), 3329-3341.

29 S. Okarvi, Recent progress in fluorine-18 labelled peptide radiopharmaceuticals, Eur. J. Nucl. Med., 2001, 28(7), 929938.

30 O. Jacobson, D. O. Kiesewetter and X. Chen, Fluorine-18 radiochemistry, labeling strategies and synthetic routes, Bioconjugate Chem., 2015, 26(1), 1-18.

31 D. E. Olberg and O. K. Hjelstuen, Labeling strategies of peptides with ${ }^{18} \mathrm{~F}$ for positron emission tomography, Curr. Top. Med. Chem., 2010, 10(16), 1669-1679.

$32 \mathrm{~J}$. Collins, et al. Production of diverse PET probes with limited resources: $241^{8 \mathrm{~F}}$-labeled compounds prepared with a single radiosynthesizer, Proc. Natl. Acad. Sci. U. S. A., 2017, 114(43), 11309-11314.

33 C. Collet, et al. Development of 6-[ $\left[{ }^{18} \mathrm{~F}\right]$ fluoro-carbohydratebased prosthetic groups and their conjugation to peptides via click chemistry, J. Labelled Compd. Radiopharm., 2016, 59(2), 54-62.

34 O. Jacobson, et al. Novel method for radiolabeling and dimerizing thiolated peptides using ${ }^{18} \mathrm{~F}$ hexafluorobenzene, Bioconjugate Chem., 2015, 26(10), 20162020.

35 U. Ackermann, et al. Improved synthesis of $\left[{ }^{18} \mathrm{~F}\right]$ FLETT via a fully automated vacuum distillation method for $\left[{ }^{18} \mathrm{~F}\right] 2$ fluoroethyl azide purification, Appl. Radiat. Isot., 2014, 94, 72-76.

36 D. Thonon, et al. Fully automated preparation and conjugation of N-succinimidyl $4-\left[{ }^{18} \mathrm{~F}\right]$ fluorobenzoate $\left(\left[{ }^{18} \mathrm{~F}\right]\right.$
SFB) with RGD peptide using a GE FASTlab synthesizer, Mol. Imaging Biol., 2011, 13(6), 1088-1095.

37 U. Ackermann, et al. Fully automated synthesis and coupling of $\left[{ }^{18}\right.$ F]FBEM to glutathione using the iPHASE FlexLab module, J. Labelled Compd. Radiopharm., 2014, 57(2), 115120.

38 D. E. Olberg, et al. One step radiosynthesis of $6-\left[{ }^{18} \mathrm{~F}\right]$ fluoronicotinic acid 2,3,5,6-tetrafluorophenyl ester $\left(\left[{ }^{18} \mathrm{~F}\right] \mathrm{F}\right.$ Py-TFP): A new prosthetic group for efficient labeling of biomolecules with fluorine-18, J. Med. Chem., 2010, 53(4), 1732-1740.

39 R. A. Davis and J. C. Fettinger, Crystal structure of N,N,Ntrimethyl-5-((2,3,5,6-tetrafluorophenoxy)carbonyl)pyridin-2aminium trifluoromethanesulfonate a precursor for the synthesis of 6-[ $\left.{ }^{18} \mathrm{~F}\right]$-Fluoronicotinyl-2,3,5,6-tetrafluoro phenylester, Acta Crystallogr., Sect. C: Cryst. Struct. Commun., 2018, 74(5), C74.

40 R. B. Merrifield, Solid phase peptide synthesis. I. The synthesis of a tetrapeptide, J. Am. Chem. Soc., 1963, 85(14), 2149-2154.

41 P. R. Hansen and A. Oddo, Fmoc Solid-phase peptide synthesis, in Peptide antibodies: Methods and protocols, ed. G. Houen, Springer, New York, NY, 2015, pp. 33-50.

42 R. A. Davis, et al., Solid-phase synthesis and fluorine-18 radiolabeling of cycloRGDyK, Org. Biomol. Chem., 2016, 14(37), 8659-8663.

43 M. Lazari, et al. Understanding temperatures and pressures during short radiochemical reactions, Appl. Radiat. Isot., 2016, 108, 82-91.

44 N. Malik, et al. Radiosynthesis of a new PSMA targeting ligand ([${ }^{18}$ F $]$ FPy-DUPA-Pep), Appl. Radiat. Isot., 2011, 69(7), 1014-1018.

45 F. Basuli, et al. Facile room temperature synthesis of fluorine-18 labeled fluoronicotinic acid-2,3,5,6tetrafluorophenyl ester without azeotropic drying of fluorine-18, Nucl. Med. Biol., 2016, 43(12), 770-772.

46 F. Basuli, et al. Fast indirect fluorine-18 labeling of protein/ peptide using the useful 6-fluoronicotinic acid-2,3,5,6tetrafluorophenyl prosthetic group: A method comparable to direct fluorination, J. Labelled Compd. Radiopharm., 2017, 60(3), 168-175.

47 D. O. Kiesewetter, O. Jacobson, L. Lang and X. Chen, Automated radiochemical synthesis of $\left[{ }^{18} \mathrm{~F}\right]$ FBEM: A thiol reactive synthon for radiofluorination of peptides and proteins, Appl. Radiat. Isot., 2011, 69, 410-414.

48 G. Tang, X. Tang and X. Wang, A facile automated synthesis of $\mathrm{N}$-succinimidyl 4 -[ $\left[{ }^{18} \mathrm{~F}\right]$ fluorobenzoate $\left(\left[{ }^{18} \mathrm{~F}\right] \mathrm{SFB}\right)$ for ${ }^{18} \mathrm{~F}$ labeled cell-penetrating peptide as PET tracer, J. Labelled Compd. Radiopharm., 2010, 53, 543-547.

49 R. C. Cumming, D. E. Olberg and J. L. Sutcliffe, Rapid ${ }^{18}$ Fradiolabeling of peptides from $\left[{ }^{18} \mathrm{~F}\right]$ fluoride using a single microfluidics device, RSC Adv., 2014, 4(90), 49529-49534.

50 M. Glaser, et al. Radiosynthesis and biodistribution of cyclic RGD peptides conjugated with a novel $\left[{ }^{18} \mathrm{~F}\right]$ fluorinated aldehyde-containing prosthetic group, Bioconjugate Chem., 2008, 19(4), 951-957. 
Paper

View Article Online

RSC Advances

51 R. Minamimoto, et al. Biodistribution of the ${ }^{18} \mathrm{~F}$-FPPRGD2 PET radiopharmaceutical in cancer patients: an atlas of SUV measurements, Eur. J. Nucl. Med. Mol. Imaging, 2015, 42(12), 1850-1858.

52 L. M. Kenny, et al. Phase I trial of the positron-emitting ArgGly-Asp (RGD) peptide radioligand ${ }^{18} \mathrm{~F}$-AH111585 in breast cancer patients, J. Nucl. Med., 2008, 49(6), 879-886.

$53 \mathrm{~S}$. Lu, et al. ${ }^{18} \mathrm{~F}$-labeled galacto and PEGylated RGD dimers for PET imaging of alphavbeta3 integrin expression, Mol. Imaging Biol., 2010, 12(5), 530-538.

54 R. Haubner, et al. $\quad\left[{ }^{18} \mathrm{~F}\right]$ Galacto-RGD: synthesis, radiolabeling, metabolic stability, and radiation dose estimates, Bioconjugate Chem., 2004, 15(1), 61-69.

55 R. Haubner, et al. Noninvasive visualization of the activated $\alpha_{\mathrm{v}} \beta_{3}$ integrin in cancer patients by positron emission tomography and $\left[{ }^{18}\right.$ F $]$ galacto-RGD, CLoS Med., 2005, 2(3), e70.
56 L. S. Campbell-Verduyn, et al. Strain promoted copper-free "click" chemistry for ${ }^{18} \mathrm{~F}$ radiolabeling of bombesin, Angew. Chem., Int. Ed., 2011, 50, 11117-11120.

$57 \mathrm{X}$. Chang, et al. ${ }^{18} \mathrm{~F}$-Labeled bombesin analogs for targeting GRP receptor-expressing prostate cancer, J. Nucl. Med., 2006, 47(3), 492-501.

58 G. Carlucci, et al. GRPR-selective PET imaging of prostate cancer using $\left[{ }^{18} \mathrm{~F}\right]$-lanthionine-bombesin analogs, Peptides, 2015, 67, 45-54.

59 A. C. Valdivia, et al. A fast, simple, and reproducible automated synthesis of $\left[{ }^{18} \mathrm{~F}\right] \mathrm{FPyKYNE}-\mathrm{c}(\mathrm{RGDyK})$ for $\alpha_{\mathrm{v}} \beta_{3}$ receptor positron emission tomography imaging, $J$. Labelled Compd. Radiopharm., 2012, 55(2), 57-70.

60 J. A. Inkster, D. J. Colin and Y. Seimbille, A novel 2cyanobenzothiazole-based ${ }^{18} \mathrm{~F}$ prosthetic group for conjugation to 1,2-aminothiol-bearing targeting vectors, Org. Biomol. Chem., 2015, 13(12), 3667-3676.

This journal is (c) The Royal Society of Chemistry 2019

RSC Adv., 2019, 9, 8638-8649 | 8649 